\title{
Determination of Student Opinions on Usage of Social Media and Mobile Tools in Student-Teacher, Student-Student Communication
}

\author{
https://doi.org/10.3991/ijet.v14i22.11745 \\ Hasan Denizalp $\left.{ }^{(}\right)$, Fezile Ozdamli \\ Near East University, North Nicosia, Cyprus \\ hasan.denizalp@neu.edu.tr
}

\begin{abstract}
Since Depending on technological advances, development of social media and mobile applications today reshape communication, education and teaching system. The extent to which social media and mobile applications which are especially used by new generation youth frequently will be beneficial in student-teacher and student-student communication is becoming more and more important. This research is based on the opinions of students on the usage of social media and mobile applications in education which take considerable time of teachers and students, social networks and mobile applications were used with the purpose of communication in science and communication technologies for 12 weeks. Thirty-five teacher candidates attended the study. At the end of the application interviews were held with 20 students and according to the findings obtained, an effort was paid to determine the impact of social media and mobile applications in student-teacher and student-student communication. Discussions and recommendations on obtained findings were presented.
\end{abstract}

Keywords - Social media; mobile applications; social networks

\section{Introduction}

In Today technology is offering facilities to the lives of every person and, through internet, it allows for fast communication. The use of smart phones with the rapid development of technology makes the Internet widespread. Chat rooms, virtual communities, social networks, wikis, blogs, or video sharing sites become people's living centers [1]. Especially social networks and mobile applications carried communication in education to a different dimension. Today when social networks and mobile applications are used so densely, using technology not only for leisure activity but also for educative purposes is very critical in the efficiency of communication in teacher-student relation. Many social network sites and mobile applications created today have reshaped interaction process of people. Within this scope, many people are using social networks and mobile applications thanks to technology and internet and the number of people using this technology is increasing on a daily basis [2].

For teachers and students who always use social media and mobile applications there is an advantage as well as some limitations. These applications make communication easier for teachers and it can accelerate education process when it is used in the right time. Social media and mobile applications which can be used online allows for 
synchronized and non-synchronized realization of communication between teacher and student [3]. Some disadvantages for students are the financial status of students, geographical conditions of students, limited access to internet or speed problems, and storing problems, among others [4].

Today technology is that intertwined with education and covers both individual and cooperative works; adding to the addiction of young people to technology education becomes more attractive and interaction is made easier. Thus, time is saved in studies conducted by students in groups and learning becomes more efficient for students. Computers, phones and tablet computers address to almost every age group and have become indispensable for online education media $[5,6,7]$. When the literature about learning and teaching is considered, it is defined that in-class activities are insufficient and extra-class activities must be included so as to create an effective media $[8,9,10$, $11,12,13,14,15,16]$. However, many teachers state that students do not show sufficient effort in extra-class activities. Allessi and Trollip [17] state that this is due to lack of motivation. With mobile technologies students can organize extra-class activities by increasing their motivations without just sitting in front of a computer. According to Low and O'Connel [18], m-learning increases flexibility in the field of learning and mobile learning tools give more sense of freedom to students compared to classroom environment.

In his research on teacher candidates, Teke [19] found out that technology usage of teachers showed difference according to the departments but not according to the genders or grades of teachers and, concluded that, when the time they spent in social media is considered, positive contribution is made, albeit little, in terms of education.

Dimitriadis, Rubia, Gomez \& de la Fuente [20] studied the relation between cooperative learning and social media and found out that it had positive impact on both organizations and people.

In a study conducted among prospective teachers, the study was conducted using a mixed research model and the effect of social network supported micro learning on selfefficacy and learning skills was investigated. As a result of this research, it was seen that social network supported micro learning increased the teacher's self-efficacy level in terms of classroom management and learning method. In another study, students' perceptions of social media usage and academic performance were investigated. As a result of the study, it has been revealed that the duration of social media usage has no effect on academic performance [21, 22]

The facts that teachers using social media and mobile application are constantly in contact with their students and perform learning in that manner and that studies on the education results of participation of students in course-based social networks added a new viewpoint to the topic. Social media applications and mobile applications are today providing very good opportunities for creating online groups and continuing communication and education through these groups [23]

The increasing employability of social media and mobile applications today urged several educators to use them with the purpose of facilitating learning and increasing communication with students in their classes. Although most teachers are using these applications in their classes, it is known that there are educators who believe that this 
technology leads to problems and do not prefer to use them as it reduces the motivation of students [24, 25].

The purpose of this study is to determine the student opinions as regards studentteacher and student-student communication of learning process supported by social media and mobile applications.

\section{Methodology}

\subsection{Research method}

Qualitative method was used in this study with the purpose of identifying the student opinions on social network and mobile applications.

\subsection{Participants}

Study group of the research consists of 35 teacher candidates who take Information and Communication Technologies course in Pre-School Teaching department. Of the teacher candidates who took part in the study, 24 are females and 11 are males. The median age of teacher candidates is 20 . Social media tools and mobile applications were used in the research. Especially a Facebook group was created for the course and course materials were shared through the group. In addition, WhatsApp group was formed from mobile applications and student-teacher and student-student communication was supported. In the beginning of the semester it was identified that all students had smart phones and internet connection. It was performed as a support for classes taught in laboratory environment for 12 weeks. Cooperative learning groups were created in the 2 nd week of the course and projects were assigned to students. In the 12th week projects were uploaded to Facebook group and presented by group leaders in laboratory environment. Semi-structured interview forms were prepared by researchers and presented to the opinions of education technocrats. Some adjustments were made in line with expert opinions. At the end of the application, interviews were made with 20 teacher candidates. Reliability of the interviews was ensured by the researcher. Interviews were recorded on phone upon permission. Each interview took approximately 10 minutes. Content analysis was made from the obtained data. In order to ensure the reliability of the findings, one researcher analyzed texts whereas another one double-checked the findings. Identities of teachers were kept confidential and indicated with numbers during reporting (student1, student2). 
Facebook

Uyeler

Kişi ekle

97. Abclullah Parildar

Qaparildarl

Alpay Ince

Qalpay.ince.14

(2) Arda Özkan

DÍĞERLERINII GÖR (22)
WhatsApp

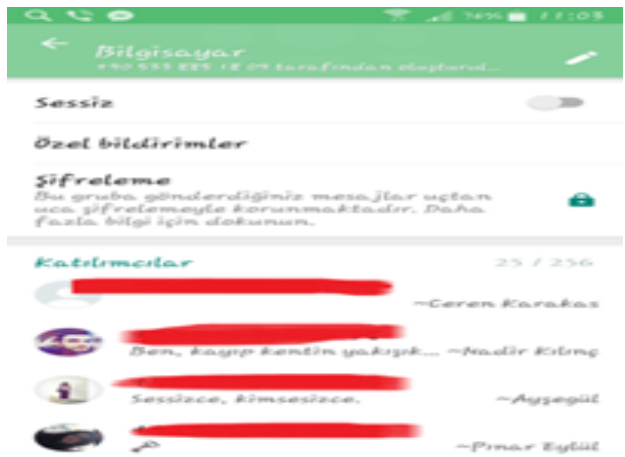

\section{Results and Discussion}

When the answers given by teacher candidates to questions asked with the purpose of determining the courses where they used mobile applications and social media tools for communication purposes are examined, it can be seen that they used these media effectively in Information and Communication Technologies Music Teaching, Teaching Technologies and Material Design, Special Teaching Methods and Education Psychology courses. The findings obtained from the questions asked as regards communication according to the purpose of the research are presented below.

\subsection{Advantages of social media and mobile application tools}

The answers given to the question "what kind of advantages did usage of social media and mobile applications in Computer and Communication Technologies (BIT) Class provide you?" which was asked to pre-school teaching department students, such themes as "being aware", "communicating with the teachers", "follow-up of information whenever I want", "information exchange with my friends", "ability to pursue the class", "performing cooperation", "saving time" were obtained. The frequencies of these themes are given below.

Table 1. Advantages of using social media and mobile application tools in BIT class

\begin{tabular}{|c|l|c|}
\hline No & \multicolumn{1}{|c|}{ Parameters } & f \\
\hline 1 & Information exchange with my friends being aware & 14 \\
\hline 2 & Communicating with the teacher's ability to pursue the class & 9 \\
\hline 3 & Follow-up of information whenever I want developing & 9 \\
\hline 4 & Cooperation & 7 \\
\hline 5 & Saving time & 6 \\
\hline
\end{tabular}

As can be seen in the table above, it was stated that usage of social media and mobile applications in information and communication technologies class by teacher 
candidates who participated in the study has several advantages. Employment of these applications in education ensured that teachers easily perform exchange of information with their friends and interact about the class. Some of the opinions stated by the students are as follows:

- Student 1: "Using social media we can reach each other; become aware of developments related to the class when we miss class, and communicate with our teacher more easily."

- Student 4: "It provided convenience in terms of communicating with each other. I exchanged information with my friends and my teacher about project delivery dates and the topics I could not understand."

- Student 5: "It provided convenience in terms of communicating with my friends about my projects."

As can be seen from obtained findings, teacher candidates reached their teachers and friends through social media and mobile applications and established communication. This finding shows that using social media and mobile applications for education purposes has positive impact on the student-student and student-teacher communication.

\subsection{Usefulness of the employed social media and social applications}

In the study, students were asked the question "Were social media tools and mobile applications used in the class adequate in terms of communicating with your friends and the lecturer?" in order to identify whether social media tools and mobile applications used throughout the semester were sufficient in terms of communication. The obtained findings were themed as follows:

Table 2. Opinion on the used application

\begin{tabular}{|c|l|c|}
\hline No & \multicolumn{1}{|c|}{ Parameters } & f \\
\hline 1 & Applications used in classes are sufficient & 19 \\
\hline 2 & Only WhatsApp can be used & 3 \\
\hline 3 & Instagram and Twitter can be used & 3 \\
\hline 4 & More online applications can be used & 2 \\
\hline
\end{tabular}

Most of the teacher candidates who took part in the study thought that the applications used by lecturers in information and communication technologies class were sufficient whereas some students stated that they wanted to use only one application or different applications. The interviews given by students on this topic are as follows:

- Student12: "The used applications were adequate but I would like to use Instagram in addition to these applications."

- Student3: "I think that the applications used are adequate for establishing communication."

- Student16: "Among these applications I wish there was Twitter so as to pursue the daily developments about the class and participate". 
As can be seen from the obtained findings, some teacher candidates stated that such trendy applications as Instagram and Twitter should be used for education purposes.

\subsection{Features used in social media and mobile applications}

The aim of this study was to identify which features were most used in social media and mobile applications by teacher candidates. Within this scope, teacher candidates were asked the question "What features you use most in the social media and mobile applications in Information and Communication Technologies Class?"

Table 3. Features used in social media and mobile applications

\begin{tabular}{|c|l|c|}
\hline No & \multicolumn{1}{|c|}{ Parameters } & \multicolumn{1}{|c|}{ f } \\
\hline 1 & Photo and screen-saving & 20 \\
\hline 2 & Lecture note sharing & 16 \\
\hline 3 & Sharing lecture-related videos & 7 \\
\hline 4 & Sharing lecture-related online material & 4 \\
\hline
\end{tabular}

When the features used by teacher candidates are examined, it can be seen that they communicated both visually and audial and that students tried to solve problems mostly by sharing screen images and photos. The opinions of students on the topic are given below:

- Student11: "While using WhatsApp, I generally use the screen image sending feature as we send it to our group and help each other where we are stuck."

- Student16: "I completed missing lecture notes through the groups on social network."

- Student7: "I use it mostly for file sharing; when we have homework, we are sending the file to our teacher and receive feedback rapidly."

When the findings obtained from the opinions of teacher candidates are examined, it was found out that the most widely used feature by students was screen sharing and lecture note sending. Students stated that when they had problems in Information and Communication Technologies class, they used screen sharing feature and received help from each other and the lecturer.

\subsection{The importance of student-teacher and student-student communication}

As Teacher-student and student-student communication plays an essential role in learning process. In this context, the teacher candidates were asked the question "from which perspective is supporting student-teacher and student-student communication with social media and mobile applications important?" so as to identify their awareness on communication. The obtained opinions were themes as follows: 
Paper-Determination of Student Opinions on Usage of Social Media and Mobile Tools...

Table 4. Importance of student-student and student-teacher communication

\begin{tabular}{|c|l|c|}
\hline No & \multicolumn{1}{|c|}{ Parameters } & f \\
\hline 1 & Effective communication & 12 \\
\hline 2 & Instant communication & 9 \\
\hline 3 & Mutualisation & 4 \\
\hline 4 & Lower costs & 4 \\
\hline
\end{tabular}

When the opinions obtained from students are examined, it can be seen that most students stated that social media and mobile applications were effective for effective communication and that problems could be solved more easily and healthily through screen sharing features which contributed to communication as it did not require any cost:

- Student1: "I think that it is very important for understanding each other and making empathy between student and teacher. Social media and mobile applications allow us to communicate instantly with low cost."

- Student8: "I think that we have healthy communication through social media and mobile applications. We completed our projects with instant screen sharing."

- Student14: "Communication between student and teacher continues outside class through social networks and mobile applications, which ensures uninterrupted communication."

As can be seen from the obtained findings, teacher candidates think that using social media and mobile applications in class provides effective communication and they have to be used in other classes as well.

\section{Conclusion and Recommendations}

This study was conducted with the purpose of determining the opinions of teacher candidates on usage of social media and mobile applications in student-student and student-teacher communication. Thirty-five teacher candidates at pre-school teaching department took part in this study which was conducted in Information and Communication Technologies class and the classes which were taught for 12 weeks were supported by social network and mobile applications in laboratory environment. At the end of the study findings were obtained from 20 students upon which conclusions are drawn and discussion is made.

According to the results obtained from the study, teacher candidates revealed that in classes where they did not use these applications, they had difficulty in communicating with lecturers and fell behind updated information on the lecture. It was found out that the social networks and mobile applications used by students had positive impact on student-student and student-teacher communication.

As for the advantages brought by using social media and mobile application tools in ICT class, exchange of information between students was the most prominent advantage which made contribution to the cooperative works between students. In addition, students were noticed about information on the class who could pursue the class 
easily. In a similar vein, Dağ's [26] study concluded that with social media and mobile applications students could more easily solve the problems with their friends and teachers through cooperation and healthy communication and that learning developed in a positive direction. In addition, Tinmaz's [27] study concluded that students could express themselves more comfortably with social media and mobile applications used in ICT class and showed more active participation in class which improved their motivation.

In conclusion, with this study which was based on the usage of social media and mobile applications in teaching, usually positive results were obtained on the usage of social media and mobile applications by pre-school teaching department students. However, this study has some limitations just like all studies. The most important limitation of this research is that it uses qualitative method. In order to add more depth to this research, qualitative method can be supported by quantitative method. It is hoped that this research will guide future studies.

\section{Acknowledgement}

The aAuthors acknowledge and thank all students who spent their valuable time by participating in this study.

\section{References}

[1] Direktor, C., Nuri, C., Okray, Z., \&HuseyinzadeSimsek, A. (2019). The relationship between social sharing sites users' personality beliefs and purposes of using social sharing sites of university students. Cypriot Journal of Educational Sciences, 14(2), 313-321. https://doi.org/10.18844/cjes.v14i2.4132

[2] Gülbahar, Y., Kaleli, F. \&Madran, O. (2011). SosyalAğlarınEğitimAmaçlıKullanımı. Internet in Turkey Conference XV İstanbul Technical University, İstanbul.

[3] Özmen, F., Aküzüm, C., Sünkür, M. \&Baysal, N. (2011). SosyalAğSitelerininEğitselOrtamlardakil̇şlevselliği, (May), 16-18.

[4] Ekrem, G. veKesim, M. (2016). Mobil iletişimteknolojilerindekigelişmelervemobilöğrenme. Auad, Dergisi, 2, 36-51.

[5] Ekici, M., \&Kıyıcı, M. (2012). Using social networks in educational context. Uşak University Journal of Social Sciences, 5(2), 156-167.

[6] Bengisoy, A. (2017). Examination of tablet usage by 4 years old pre-school student. World Journal on Educational Technology: Current Issues, 6(3), 158-164. https://doi.org/10. 18844/wjet.v6i3.2062

[7] Şakar, B. E., Gökbay, İnci Z., \&Karahoca, A. (2016). Assessment of readinessfor learning andacademicsuccess on computerassistedlearning: A study on computerintegratedmanufactur-ingwithlathe. Global Journal of Information Technology: Emerging Technologies, 6(1). https://doi.org/10.18844/gjit.v6i1.396

[8] Song, Y., \& Kong, S. C. (2017). Affordances and constraints of BYOD (Bring Your Own Device) for learning and teaching in higher education: Teachers' perspectives. Internet and Higher Education, 32, 39-46. https://doi.org/10.1016/j.iheduc.2016.08.004 
[9] Yusri, I. K., Goodwin, R., \& Mooney, C. (2015). Teachers and Mobile Learning Perception: Towards a Conceptual Model of Mobile Learning for Training. Procedia - Social and Behavioral Sciences, 176, 425-430. https://doi.org/10.1016/j.sbspro.2015.01.492

[10] Saran, M. (2009). Exploring the use of mobile phones for supporting English language learners' vocabulary acquisition. Unpublished PhD Thesis, Middle East Technical Universi-ty, Faculty of Education Sciences, Turkey

[11] Kanbul, S., \& Uzunboylu, H. (2017). Importance of Coding Education and Robotic Applications for Achieving 21st-Century Skills in North Cyprus. International Journal of Emerging Technologies in Learning,12 (1) 130-140. https://doi.org/10.3991/ijet.v12i01.6097

[12] Sürmelioğlu, Y., \& Seferoğlu, S. (2019). An examination of digital footprint awareness and digital experiences of higher education students. World Journal on Educational Technology: Current Issues, 11(1), 48-64. https://doi.org/10.18844/wjet.v11i1.4009

[13] Soykan, E. (2015). Views of students, teachers and parents on the tablet computer usage in education. Cypriot Journal of Educational Sciences, 10(3). https://doi.org/10.18844/cjes. v1il.68

[14] Byker, E., Putman, S., Handler, L., \& Polly, D. (2017). Educational Technology and Student Voice: Examining Teacher Candidates' Perceptions. World Journal on Educational Technolo-gy: Current Issues, 6(3), 119-129. https://doi.org/10.18844/wjet.v6i3.1687

[15] Abramauskienè, J. (2016). Thecharacteristics of applyingcomputertechnologies in the process of musicaleducation. Global Journal of Information Technology: Emerging Technologies, 5(2), 95-100. https://doi.org/10.18844/gjit.v5i2.199

[16] Aleksandrova, Y., \& Parusheva, S. (2019). Social Media Usage Patterns in Higher Education Institutions-An Empirical Study. International Journal of Emerging Technologies in Learning, 14(5). https://doi.org/10.3991/ijet.v14i05.9720

[17] Alessi,S.M., \& Trollip, S.R. (2001). Multimedia for learning: Methods and development. Boston, MA: Allyn \& Bacon.

[18] Low, L., \& O’Connel M. (2006). Learner-centric design of digital mobile learning. Web: http://online.cit.act.edu.au/mlearning/lowoconnell2006.pdf Retrived on 16 April 2016.

[19] Teke, A. (2015). Öğretmen Adaylarının Eğitim Amaçlı Sosyal Ağ ve İnternet Kullanma ÖzYeterlilik Alg1ları. Journal of Education Faculty, 29 (2), 303-323

[20] Dimitriadis, Y., Rubia, B., Gomez, E. \& de la Fuente, P. (2003). Combining qualitative evaluation and social network analysis for the study of classroom social interactions, 41, 353368. https://doi.org/10.1016/j.compedu.2003.06.001

[21] Kelleci, O., Kulaksiz, T. \& Pala, F. K. (2018). The effect of social network-supported microlearning on teachers self-efficacy and teaching skills. World Journal on Educational Technol-ogy: Current Issues. 10(2), 115-129 https://doi.org/10.18844/wjet.v10i2.3456

[22] Mahdi, M. (2019). Undergraduate Students' Perceptions toward Social Media Usage and Academic Performance: A Study from Saudi Arabia. International Journal of Emerging Technologies in Learning, 14(3). https://doi.org/10.3991/ijet.v14i03.9340

[23] Imlawi, J., Gregg, D. \& Karimi, J. (2015). Computers \& Education Student engagement in course-based social networks: The impact of instructor credibility and use of communication. Computers \& Education, 88, 84-96. https://doi.org/10.1016/j.compedu.2015.04.015

[24] Açayır, G. (2017). Computers in Human Behavior Why do faculty members use or not use social networking sites for education? Technologies, Instructional, 71, 378-385. https://doi. org/10.1016/j.chb.2017.02.028

[25] Uzunboylu, H. \& Karagozlu, D. (2017). The Emerging Trend of the Flipped Classroom: A Content Analysis of Published Articles between 2010 and 2015.RED. Revista de Educación a Distancia. 54 (4). DOI: http://dx.doi.org/10.6018/red/54/4. 
[26] Dağ, I. (2015). Sosyal Ağ Kuramları Bağlamında Motivasyonun Ortaöğrenim Öğrencilerinin Akademik Başarıları Üzerindeki Etkileri, 13-22.

[27] Tinmaz, H. (2011). Utilization of social networking websites in education: a case of Facebook, (March). Contemporary Educational Technology, 3(3), 234-245.

\section{$7 \quad$ Authors}

Hasan Denizalp is PhD student at the Department of Computer Information Systems in Near East University. His interests are smartphone, m-learning, and technologybased learning environ-ment. Email: hasan.denizalp@,neu.edu.tr

Fezile Ozdamli is a lecturer at the Department of Computer Information Systems, Near East University, Cyprus. Her interests are technology, mobile learning, virtual learning environments, and distance learning. Email: fezile.ozdamli@neu.edu.tr

Article submitted 2019-09-23. Resubmitted 2019-10-23. Final acceptance 2019-10-25. Final version published as submitted by the authors. 